\title{
FURTHER OBSERVATIONS ON EUPELMINAE (HYMENOPTERA, CHALCIDOIDEA, EUPELMIDAE) IN THE IBERIAN PENINSULA AND CANARY ISLANDS, INCLUDING DESCRIPTIONS OF NEW SPECIES
}

\author{
R. R. Askew* and J. L. Nieves-Aldrey**
}

\begin{abstract}
Data on Eupelmus Dalman, additional to that presented in Askew \& Nieves-Aldrey (2000), are given here, including the location of type material of three species described by C. Bolívar. Eupelmus hungaricus Erdös is transferred to Reikosiella (n. comb.). Representation of other genera of Eupelminae in the Iberian Peninsula and Canary Islands is reviewed (Anastatus 9 spp., Arachnophaga 2 spp., Brasema 1 sp., Calymmochilus $3 \mathrm{spp}$., Merostenus $1 \mathrm{sp}$.) and keys to species are given. Three species are described as new, Anastatus maculosus Askew, A. magnoculus Askew and Calymmochilus delphinus Askew.

Key words: Hymenoptera, Chalcidoidea, Eupelmidae, Anastatus, Arachnophaga, Brasema, Calymmochilus, Eupelmus, Merostenus, Reikosiella, new species, Spain, Canary Islands.
\end{abstract}

\section{RESUMEN}

Nuevas observaciones sobre Eupelminae (Hymenoptera, Chalcidoidea, Eupelmidae) de la Península Ibérica e Islas Canarias incluyendo descripciones de nuevas especies

Se aportan datos del género Eupelmus Dalman adicionales a los presentados por Askew y Nieves-Aldrey (2000), incluyendo la localización de material tipo de tres especies descritas por C. Bolívar. Se efectúa la transferencia de Eupelmus hungaricus Erdös al género Reikosiella (n. comb.). Se revisa la representación de otros géneros de Eupelminae en la Península Ibérica e Islas Canarias: Anastatus 9 spp., Arachnophaga 2 spp., Brasema 1 sp., Calymmochilus 3 spp., Merostenus 1 sp., y se dan claves para la identificación de las especies. Se describen tres especies nuevas para la ciencia, Anastatus maculosus Askew, A. magnocolus Askew y Calymmochilus delphinus Askew. Palabras clave: Hymenoptera, Chalcidoidea, Eupelmidae, Anastatus, Arachnophaga, Brasema, Calymmochilus, Eupelmus, Merostenus, Reikosiella, especies nuevas, España, Islas Canarias.

* $\quad$ RRA: 5, Beeston Hall Mews, Beeston, Tarporley, Cheshire CW6 9TZ, England.

** JLNA: Museo Nacional de Ciencias Naturales, Departamento de Biodiversidad y Biologia Evolutiva, José Gutiérrez Abascal 2, 28006 Madrid, España. 


\section{Introduction}

The subfamily Eupelminae is represented within the Iberian Peninsula and Canary Islands by the following genera as recognized by Gibson (1995): Anastatus Motschulsky, Arachnophaga Ashmead, Brasema Cameron, Calymmochilus Masi, Eupelmus Dalman, Merostenus Walker and Reikosiella Yoshimoto.

An account has been given previously (Askew \& Nieves-Aldrey, 2000) of species of Eupelmus (including Macroneura Walker, 1837) in the region. Here we consider species in the remaining genera of Eupelminae, treated alphabetically, and also provide additional information on Eupelmus.

The following abbreviations are used: $\mathrm{CBP}=\mathrm{C}$. Bolívar y Pieltain, JBZ = J. Blasco-Zumeta, JNA = J. Nieves-Aldrey, JPV = J. Pujade-Villar, MNCN = Museo Nacional de Ciencias Naturales (Madrid), $\mathrm{RGM}=\mathrm{R}$. García Mercet, RRA $=$ R. R. Askew, ZMAN = Zoölogisch Museum Amsterdam, Nederland.

\section{Anastatus Motschulsky, 1859}

Four species of Anastatus were recorded from Spain by Bolívar (1934) and catalogued by Ceballos (1956): A. bifasciatus (Geoffroy), A. catalonicus Bolívar, A. giraudi (Ruschka) (as dolichopterus Bolívar) and A. japonicus Ashmead (as disparis Ruschka). A fifth species, A. oscari (Ruthe), was listed by Askew et al. (2001) and three more, $A$. bernardi Ferrière, A. lichtensteini (Ruschka) and A. maculosus Askew are added here. The last, and $A$. magnoculus Askew from the Canary Islands, are described as new.

\section{Key to species of Anastatus Motschulsky from Spain and the Canary Islands}

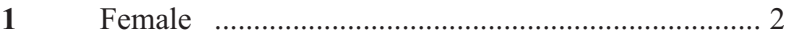

- Male ............................................................. 13

2(1) Macropterous, forewing about 2.0 times length of metatibia or longer ................................................... 3

- $\quad$ Brachypterous, forewing at most only slightly longer than metatibia

(Doubtful cases will run both ways)

3(2) White transverse band behind marginal vein of forewing with edges subparallel, not medially constricted or divided

- White transverse band behind marginal vein of forewing medially constricted or completely divided into two subtriangular spots (fig. 1)

4(3) Head in dorsal view 1.2-1.4 times as broad as long, ocelli in a slightly acute triangle; white transverse band of forewing not curved; scutellum 2.0 times as long as broad; gaster in dorsal view with weakly convex sides, broadest about the middle, with ovipositor somewhat exserted

- Head in dorsal view at least 1.7 times as broad as long, ocelli in an obtuse triangle; white transverse band of forewing curved; scutellum about 1.3 times as long as broad; gaster in dorsal view narrowed at base and broadest behind the middle, with only the pale tips of the ovipositor sheath visible

5(4) Mesoscutum with depressed area behind anterior median lobe with raised reticulate sculpture but only scattered hairs; forewing with apex clear; gaster with weak microsculpture, partly smooth and shiny; ovipositor sheath nearly 0.6 times length of metatibia oscari (Ruthe)

(the fully macropterous form has not been found in the regions covered)

- Mesoscutum with depressed area behind median lobe without distinct reticulate sculpture and strongly pilose; forewing distad of white transverse band entirely infuscate; gaster with fine but relatively strong reticulate sculpture, not shiny; ovipositor sheath at most slightly more than 0.2 times length of metatibia ........ giraudi (Ruschka)

6(4) Mesoscutum with median lobe more weakly sculptured and shiny than scutellum, almost smooth anteriorly, depressed area behind median lobe bare; prepectus and mesopleuron entirely dark and metallic

bifasciatus (Geoffroy)

(the broad-headed form eurycephalus Masi has not been noted in Spain; it has the head in front view 1.4-1.5 times as broad as high, contrasting with 1.2-1.3 times in the nominotypical form)

Mesoscutum with median lobe as strongly sculptured as scutellum, depressed area behind median lobe pilose; prepectus and mesopleuron partly testaceous, nonmetallic

japonicus Ashmead

7(3) Forewing with white transverse band strongly constricted medially, occasionally narrowly divided; antennal flagellum plus pedicel 1.7-1.8 times as long as breadth of head; scrobes separated from anterior ocellus by slightly more than a diameter of ocellus; ovipositor sheath extending beyond last tergite for a distance less than half length of metabasitarsus ........ catalonicus Bolívar Forewing with two well-separated white spots behind marginal vein (fig. 1), the separation between the two broader than length of stigmal vein; antennal flagellum plus pedicel 1.5-1.6 times as long as breadth of head; scrobes with upper limit poorly defined but separated from anterior ocellus by about three diameters of ocellus; ovipositor sheath extending beyond last tergite for a distance about equal to length of metabasitarsus ...... maculosus $\mathrm{sp} . \mathrm{n}$.

8(2) Ovipositor sheath extending beyond last gastral tergite by no more than about 0.25 times length of metatibia ............................................................... 9 Ovipositor sheath extending beyond last gastral tergite by more than 0.5 times length of metatibia ............ 11

9(8) Forewing reaching to about middle of gaster and with a straight white transverse band behind marginal vein; head in dorsal view 1.2-1.4 times as broad as long; mesoscutum with median lobe distinctly raised 
and posterior part of mesoscutum between parallel sublateral carinae without reticulate sculpture and densely pilose; axilla about 1.2 times as long as its basal breadth giraudi (Ruschka)

- $\quad$ Forewing very short, reaching only to about middle of first gastral tergite, reflexed at or beyond the middle with basal part clear and apical part uniformly brownish; head in dorsal view 1.6-1.7 times as broad as long; mesoscutum with median lobe not defined as a raised area and surface between outwardly curved sublateral carinae reticulate and sparsely pilose; axilla twice as long as its basal breadth. (Form of thorax and relatively long mesobasitarsal pegs much as in Arachnophaga species, but the toruli are not entirely below the level of the lower orbit) .... 10

10(9) Vertex much broader than an eye, shiny, with weak and mainly engraved sculpture and head in front view (fig. 5 ) with minimum separation of eyes much greater than breadth of an eye; 'thumbnail' extension to last tergite of gaster brown and opaque .... lichtensteini (Ruschka) Vertex hardly as broad as an eye, dull, with fine, raised reticulate sculpture and head in front view (fig. 4) with minimum separation of eyes about equal to breadth of an eye; 'thumbnail' extension to last tergite of gaster pale, transparent at apex ................ magnoculus $\mathrm{sp} . \mathrm{n}$.

11(8) Mesoscutum with median lobe extending over half its length, with weak reticulate sculpture and moderately shiny; torulus with lower margin below lower orbit; gaster dorsally partly smooth and shiny; ovipositor sheath (distal to basal constriction) 0.6 times as long as metatibia; forewing with apex clear and a white transverse band behind marginal vein .......... oscari (Ruthe)

- Mesoscutum with median lobe extending over less than half its length, relatively dull with strigose-reticulate sculpture; torulus with lower margin slightly above lower orbit; gaster dorsally not shiny, with weakly raised reticulate sculpture on tergites 3-7; ovipositor sheath (after basal constriction) 0.7-0.9 times as long as metatibia ........................................................... 12

12(11) Forewing without or with a very faintly indicated transverse white band; ovipositor sheath brown with tip contrastingly pale; basal gastral tergite brownish ..

bernardi Ferrière

- $\quad$ Forewing with a distinct transverse white band behind apical half of marginal vein; ovipositor sheath reddish yellow with the tip slightly paler; basal gastral tergite white ruficaudus Ferrière

[A. ruficaudus has not been found in Spain and Portugal]

13(1) Antenna with clava very elongate and with five short funicle segments whose combined length is much less than half that of clava

bifasciatus

- $\quad$ Antenna with clava not unusually elongated and with seven funicle segments (fig. 3) ............................... 14

14(13) Forewing ( $c f$ fig. 1) infumate except at base and apex and with transverse white band behind marginal vein divided by infumation; forewing costal cell medially with only a single row of undersurface hairs; antennal scape mostly testaceous; scutellum with relatively broad base occupying more than one-third of the distance between posterior ends of notauli maculosus sp. $\mathrm{n}$.

- $\quad$ Forewing clear; forewing costal cell medially with three or more complete longitudinal rows of under- surface hairs; scape either entirely dark-coloured or bicoloured metallic green and yellow; scutellar base narrower

15(14) Metatibia bicoloured with basal one-fifth to almost half yellow; mesotibia with outer surface yellow; maxillary palp yellow; scape about twice as long as broad, ovoid, yellow basally and ventrally .................................... 16

- Metatibia without a broad basal yellow band; mesotibia almost entirely brown; maxillary palp with at least its apical segment brownish; scape sometimes otherwise

16(15) Head in dorsal view 1.6-1.7 times as broad as long; metatibia broadly pale at apex and base ........ giraudi Head in dorsal view 1.75-1.8 times as broad as long; metatibia with apex dark or only narrowly pale ............. catalonicus

17(15) Scape 2.3-2.5 times as long as broad, paler beneath but not marked with yellow; metatibia entirely dark; body black with bluish and dark violet tints

bernardi (and ruficaudus) Scape about twice as long as broad, metallic green with yellow stripe ventrally; metatibia with base and apex usually narrowly pale; body mainly green with copper and violet tints

japonicus

\section{A. bernardi Ferrière, 1954: 15-16}

New record for Iberian Peninsula: Barcelona, Osona, $900 \mathrm{~m}$ Balenya, Mas Mirambell, Malaise trap 17-21.viii.1993, C. Rey, 2 우 우 $20^{7} \sigma^{7}$ (MNCN).

Anastatus bernardi is very close to A. ruficaudus Ferrière, 1954. The latter is a common species in south-west France but has not been recorded from Spain. Females of the two can be distinguished by the colour characters given in the above key, but the differences are slight and it is not certain that two species are involved. Anastatus ruficaudus has page priority over $A$. bernardi and is an egg parasitoid of Tettigoniidae.

\section{A. bifasciatus (Geoffroy in Fourcroy, 1785: 388) \\ Cynips bifasciatus Geoffroy in Fourcroy, 1785}

Bolívar (1934) reported this species from Barcelona, Madrid, Pontevedra, Santander and Valencia, specimens from the last named province being reared from eggs of Dendrolimus pini (L.) (Lep., Lasiocampidae). Most of this material is in MNCN with additional specimens from Madrid (El Ventorillo and El Pardo, Malaise trap, 1988 and 1991, JLN).

Further records: Majorca, ex eggs Charaxes jasius L. (Lep., Nymphalidae) (H. G. Allcard); Barcelona, ex eggs Iphiclides podalirius feisthamelii Duponchel (Lep., Papilionidae) (JPV); Huesca, Jaca (RRA). 
None of the Spanish specimens examined belongs to the form eurycephalus Masi.

\section{A. catalonicus Bolívar, 1934: 284-286}

Bolívar described this species from a single female taken on Quercus in Gerona (RGM), but the type cannot be found in MNCN. 1 ㅇ, Malaise trap, El Pardo, Madrid, 1991, JNA (MNCN) is the only other Spanish female so far known, but males have been identified from Huesca, Biescas and Jaca, 1973, RRA; La Coruña, Porto do Son, Monte Muño, 1984, JNA; Madrid, El Pardo, 1989, A. Garrido (MNCN); Zaragoza, Pina de Ebro, 1991 and 1992, JBZ, and from the Canary Islands, La Palma, Santa Cruz, 1985, A.C. \& W.N. Ellis.

Ferrière (1954) recorded A. catalonicus as a parasitoid in eggs of Iris oratoria (L.) (Mantidae) in France.

\section{A. giraudi (Ruschka, 1921: 298-9)}

Eupelmus giraudi Ruschka, 1921

Anastatus dolichopterus Bolívar, 1934: 290-292 (synonymy suggested in Ferrière, 1954, confirmed in Boucek, 1977)

All Iberian females of this species seen by us belong to the macropterous form, which was described as dolichopterus by Bolívar from two females from Madrid province (El Escorial and Puerto Somosierra). The specimen from El Escorial was designated 'tipo' by Bolívar (1934) and has not been found in MNCN. The other specimen, however, is very probably one located in MNCN labelled only 'Somosierra, Mercet'; this has now been labelled as paratype of Anastatus dolichopterus Bolívar.

Additional records are from Madrid, El Pardo, 1928, RGM and 1991, JNA (MNCN), Montarco, 1918 (MNCN), Vellón, 1974, RRA and many specimens of both sexes from a Malaise trap at $1480 \mathrm{~m}$, El Ventorillo, 1988 and 1989, JNA (MNCN, 1 우 det. A. giraudi by G. Gibson 1991). The species is known also from the Canary Islands, La Palma, Parque Nacional de la Caldera de Taburiente, 2000, T. Domingo Quero (MNCN).

A. japonicus Ashmead, 1904: 153

Anastatus bifasciatus var. disparis Ruschka 1921: 265-267

(synonymy in Tachikawa, 1965; see Kalina, 1981)

Anastatus disparis; Bolívar, 1923: 119-121

Bolívar (1934) under the name $A$. disparis cited records from localities in the provinces of Jaén, Madrid, Salamanca and Segovia. Most of the specimens referred to were found in $\mathrm{MNCN}$. More recent material has been collected in Granada, Calahonda, 1987, L. Lockey; Madrid, El Pardo, 1991, JNA; Zaragoza, Pina de Ebro, 1990 and 1992, JBZ. A male A. japonicus was reared in 1997 from an egg of Iphiclides podalirius feisthamelii Duponchel (Lep., Papilionidae) from Barcelona (JPV).

A. lichtensteini (Ruschka, 1921: 301)

Eupelmus lichtensteini Ruschka, 1921

Anastatus ameleophagus Bernard, 1935: 208-212 (synonymy in Ferrière, 1954)

New record for Spain: Cuenca, Motilla del Palancar, 24-29.v.1987, M. J. Gijswijt, 1 ㅇ․

Anastatus lichtensteini (as ameleophagus) has been reared from oothecae of Ameles decolor (Charpentier) and less commonly from A. abjecta (Cyrillus) and Iris oratoria (L.) in south-east France (Bernard, 1936).

There are six of Bernard's original mounts of $A$. ameleophagus in the Muséum National d'Histoire Naturelle in Paris bearing 8 $ᄋ$ 을 and $20^{\top} 0^{\top}$, and we are informed by G. Gibson (pers. com.) that there are $30^{x} 0^{x}$ and $6 \%$ 우 in the Natural History Museum, London labelled as 'cotypes'. Bernard (1935) mentioned 7 우 우 $30^{7} 0^{\pi}$ as 'types', emerging in August from oothecae of Ameles collected at Fréjus. A female in the Muséum National d'Histoire Naturelle, in good condition, mounted by itself and agreeing well with Bernard's description, is labelled 'Fréjus (Var) èclos viii.34 F. Bernard', Anastatus ameleophagus $ᄋ$ F. Bernard' and 'TYPE' in red print. To avoid possible confusion resulting from the split type series, this specimen is selected as lectotype and has been labelled accordingly.

Anastatus maculosus Askew sp. n. (figs 1-3)

MAterial: Holotype 오. Spain, Almería, Mojácar, ex small mantid ootheca, collected 2.iv.1999 emerged iv.1999, M. D. Bryan. Deposited in MNCN.

Allotype $\sigma^{\pi}$. Same data as holotype.

Paratypes. 1 우 $30^{7} 0^{7}$, same data as holotype; 3 우 우 $10^{\pi}$, Spain, Mallorca, Cala Ratjada, ex small mantid ootheca, collected 19.xi.1992, M. Boness; 8 우 우, Greece, Kos, ex small mantid oothecae collected from castle wall 12.iv.1982 emerged xii.1982, R. R. Askew. Some to be deposited in MNCN, the Natural History Museum (London) and the National Museums of Scotland (Edinburgh).

ADDitionAL MATERIAL. 1 ㅇ $10 \sigma^{7} \sigma^{x}$, same data as holotype, damaged; 1 ㅇ $10^{7}$, Mallorca, Cala Ravinda, ex mantid ootheca, collected 13.xii.1990, M. Boness; $10^{7}$, Portugal, Algarve, Ferragudo, 15.x.1999, M. Boness.

FEMALE. Body dark green with coppery tints mainly on face, scutellum and axillae; pronotum, prepectus and mesopleuron non-metallic from dark brown (holotype) to testaceous; gaster with second tergite brownish, paler than rest of gaster but not white; ovipositor sheath light brown. Antenna with 
scape light brown, pedicel dark with green reflections, flagellum dark brown with weak coppery reflections. Forewing brown at base of basal cell and from proximal end of parastigma to wing apex but with two clear spots behind marginal vein (fig. 1), pilosity pale on clear spots, dark on brown areas; hind wing clear. Legs with femora and tibiae brown, the ventral surfaces rather paler than the dorsal; tarsi with claws and two apical segments dark brown, basal tarsal segments paler, mesotarsus with first three segments brownish white, the ventral pegs dark brown. Length 2.8-3.1 mm.

Head in dorsal view 1.7 times as broad as long; temple 0.4 times length of eye; POL 3 times OOL. Head in front view 1.15 times as broad as high; minimum separation of eyes 0.42 times head breadth; torulus with upper margin about level with lower orbit; scrobes separated from anterior ocellus by just over three diameters of ocellus, their outer edges raised. Antenna with pedicel plus flagellum 1.6 times as long as breadth of head; scape as long as height of eye; flagellum (fig. 2) clavate, anellus transverse, first funicle segment (Fu1) narrower than pedicel and more than 3 times as long as broad, $\mathrm{Fu} 2$ to $\mathrm{Fu} 7$ progressively broader and shorter; clava with ventral surface concave in air-dried material and appearing obliquely truncate from some angles.

Mesosoma (excluding prothorax) in dorsal view 1.4 times as long as broad; mesoscutum with median lobe occupying two-thirds of mesoscutal length, as strongly reticulate as scutellum and axi1la, rather dull, the depressed area behind median lobe with very weak reticulate sculpture laterally and smooth and shiny medially, moderately pilose; scutellum about 1.5 times as long as broad; mesopleuron shiny, the anterior 0.4 faintly reticulate with white and slightly flattened pilosity, posteriorly finely striate. Legs with apex of protibia with 3-4 small spines in front; mesotarsal segments ventrally with two rows of brown, darker-tipped pegs (holotype has 11-12 pegs in each row on basitarsus, 5 on T2, 3-4 on T3, 1 on T4).

Forewing (fig. 1) densely pilose except dorsal half of basal cell, but hairs white and difficult to see on clear spots; ratio of lengths of costal cell: marginal vein: stigmal vein: postmarginal vein as 32:27:5:13.

Gaster excluding ovipositor sheath longer than mesosoma (42:32), 2.3 times as long as broad, broadest behind middle; ovipositor sheath exserted for a distance about 0.37 times length of metatibia.

MALE. Head and mesosoma predominantly violet with some dark green reflections on lower face.
Antenna with scape light brown, pedicel and flagellum darker with clava and last two funicle segments dark brown. Forewing patterned as in female. Length 2.2-2.4 mm.

Antenna (fig. 3) with scape excluding radicle just over twice as long as broad, narrow in basal half and expanded in apical half with a flat, smooth area occupying upper half of anterior face; pedicel plus flagellum 1.8 times as long as breadth of head; Fu1 3.3 times as long as pedicel and 3.8 times as long as broad, slightly bent; Fu2 to Fu7 of equal breadth but progressively shorter, $\mathrm{Fu} 7$ subquadrate, all funicle segments with short linear sensillae in irregular transverse rows and extremely short pilosity; clava with intersegmental divisions hardly visible.

Mesonotum with notauli shallow posteriorly; scutellum 1.5 times as long as broad, its base about 0.6 times breadth of an axilla. Propodeum medially 0.25 times length of scutellum, median carina absent, sculpture fine and weakly engraved.

Forewing with pilosity as in female; ratio of lengths of costal cell: marginal vein: stigmal vein: postmarginal vein as 32:20:6:14.

Gaster almost or quite as long as mesosoma.

Etymology. Maculosus (Latin), spotted. Refers to the white wing spots present in both sexes.

Comments. Female A. maculosus most closely resemble $A$. catalonicus Bolívar, the two species having similar thoracic sculpture with the median lobe of the mesoscutum strongly reticulate and relatively dull and the posterior depressed area partly smooth and shiny. The white transverse band on the forewing of female $A$. catalonicus is medially constricted and occasionally completely divided by a narrow infuscate 'bridge', but in A. maculosus the two white spots derived from the transverse band are always well-separated. Female A. maculosus has a longer ovipositor sheath and shorter antennal scrobe than $A$. catalonicus, as described in the key, and the antennal toruli are slightly higher on the face. Males of the two species are very distinct, the forewing of A. maculosus being patterned as in the female but that of $A$. catalonicus being clear; in addition, the antennal scape, maxillary palp and metatibia of $A$. maculosus are brownish whilst these parts in A. catalonicus are more or less marked with yellow.

Biology. Anastatus maculosus is a parasitoid in oothecae of Mantidae. All reared specimens seen have emerged from similar small (about $15 \mathrm{~mm}$ long) oothecae which are probably those of Ameles. Bernard (1936) found A. ameleophagus (= A. lich- 

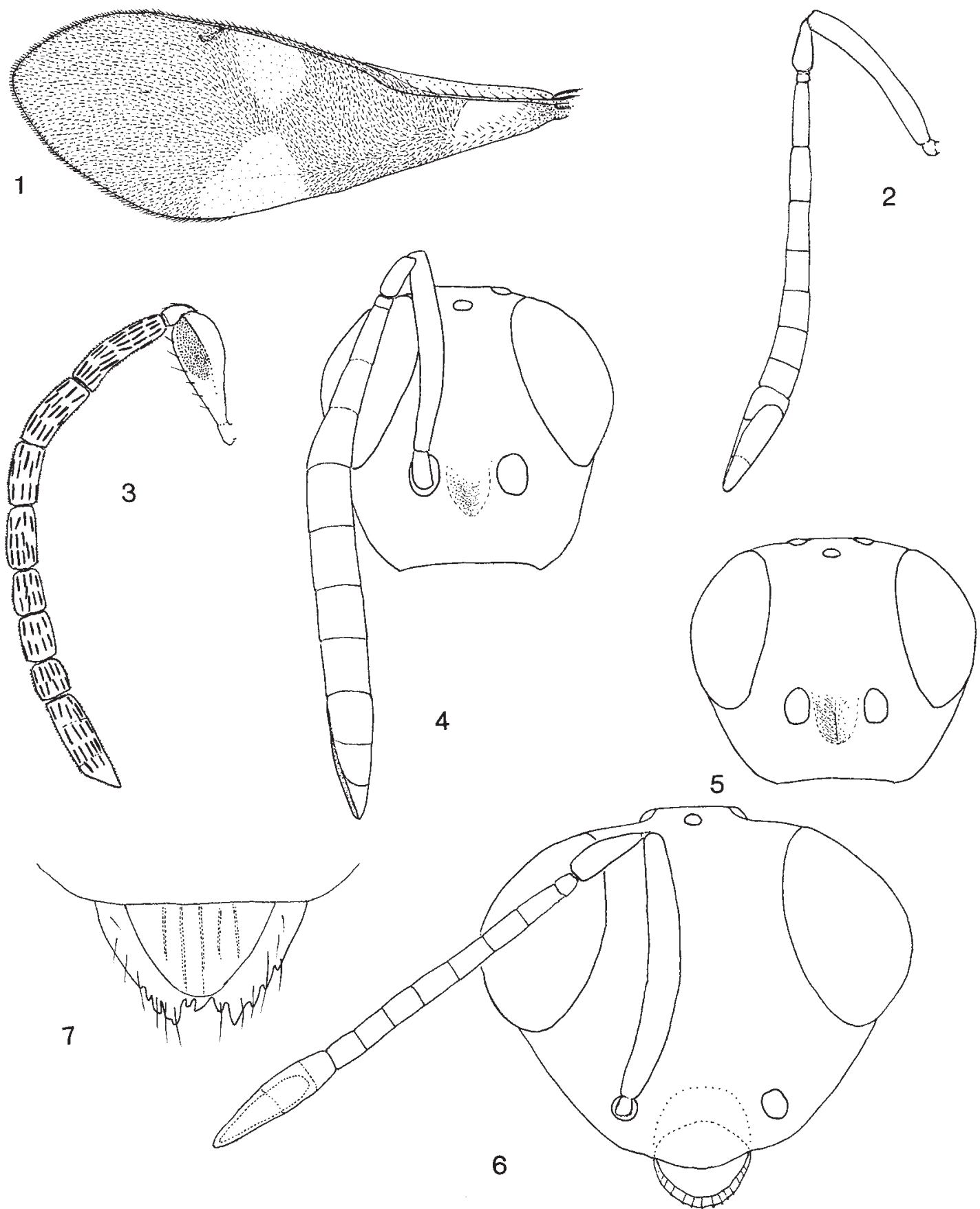

Figs. 1-7.-1) Anastatus maculosus sp. nov., 우 left forewing; 2) A. maculosus, 우 right antenna, inner aspect; 3) A. maculosus, $\sigma^{7}$ left antenna, outer aspect; 4) A. magnoculus sp. nov., 우 head in frontal view with right antenna; 5) A. lichtensteini, 우 head in frontal view (lectotype of $A$. ameleophagus Bernard); 6) Calymmochilus delphinus sp. nov., $ᄋ$ head in frontal view with right antenna; 7) C. dispar, ㅇ clypeus.

Figs. 1-7.- 1) Anastatus maculosus sp. nov., 우 ala anterior izquierda; 2) A. maculosus, $\odot$ antena derecha, aspecto interior; 3) A. maculosus, $\sigma^{\top}$ antena izquierda, aspecto exterior; 4) A. magnoculus sp. nov., $ᄋ$ cabeza en visión frontal con antena derecha; 5) A. lichtensteini, 우 cabeza en visión frontal (lectotipo de A. ameleophagus Bernard); 6) Calymmochilus delphinus sp. nov., 우 cabeza en visión frontal con antena derecha; 7) C. dispar, ㅇ clípeo. 
tensteini) and Arachnophaga picardi (Bernard) as parasitoids in oothecae of Ameles spp. (mainly $A$. decolor) near Fréjus and Nice, France, but made no mention of anything resembling $A$. maculosus.

\section{Anastatus magnoculus Askew sp. n. (fig. 4)}

Material: Holotype ㅇ․ Canary Islands, Tenerife, Las Cañadas, Malaise trap, 17.viii.1996, A. Camacho. Depository $\mathrm{MNCN}$

Female. Head dark green with violet tints on vertex and gena; mesosoma of various shades of brown, the ventral surface lighter than the dorsal, scutellum with very weak violet reflections; gaster white at base, elsewhere dark brown with weak violet reflections; 'thumbnail' extension of last tergite entirely brown; ovipositor sheath brown with apical one-third or so pale. Antenna with scape light brown, flagellum dark brown. Forewing with basal half clear, apical part distal to flexure brown. Legs brown, metatibia the darkest; basal four segments of mesotarsus whitish; basal two segments of metatarsus white. Length $3.0 \mathrm{~mm}$.

Head in dorsal view 1.65 times as broad as long; temple 0.4 times length of eye; POL about 2.5 times OOL, posterior ocellus separated from orbit by about its diameter; eye relatively large, its breadth about 1.15 times that of vertex; vertex dull with raised reticulate sculpture. Head in front view (fig. 4) only slightly broader than high; torulus with centre about level with lower orbit, intertorular prominence relatively large, strongly reticulate and rounded, without a median carina; scrobes finely reticulate, separated from anterior ocellus by about two diameters of ocellus. Antenna (fig. 4) with pedicel plus flagellum 1.9 times breadth of head (left antenna missing after Fu3); scape slightly longer than height of eye (12:11); flagellum expanding to apex of Fu3, thereafter of constant width to clava; pedicel in dorsal view twice as long as broad; anellus about 1.5 times as broad as long; funicle segments all of approximately similar length; anellus plus Fu1 1.4 times as long as pedicel; Fu1 at base as broad as pedicel, slightly broader at apex, 2.4 times as long as apical breadth; Fu2 1.8 times as long as broad; Fu3 1.3 times as long as broad at apex, 2.5 times as broad as pedicel; Fu4-Fu7 of approximately similar dimensions, only slightly longer than broad; clava with entire ventral (outer) face flattened, in profile tapering to a point; vestiture of flagellum consisting of dense and very short, adpressed hairs.
Mesosoma (excluding pronotum) in dorsal view 1.5 times as long as broad; mesoscutum without a raised median lobe anteriorly, its entire surface between the curved sublateral carinae with raised reticulation, fine medially but quite coarse at the sides, and sparse pilosity; scutellum 1.7 times as long as broad; mesopleuron densely, longitudinally striate in posterior half, anteriorly shiny with hardly discernible sculpture and fine hairs. Protibia with 6 small,dark spines at apex; mesofemur flattened (as is normal in Anastatus); mesotarsal segments ventrally with two rows of rather long, pale but dark-tipped pegs, the basitarsus with 13 in anterior row, 15 in posterior row, T2 with 5, T3 with 2, T4 with 1 in each row; metatarsus notably thin, narrower than protarsus.

Brachypterous, forewing reaching only to posterior half of first gastral tergite, reflexed upwards at about middle, venation not visible, apex rounded.

Gaster about as long as rest of body; last tergite with 'thumbnail' extension strongly produced, about as long as basal breadth and overlying much of ovipositor sheath so that in dorsal view only the pale apex of the latter is visible; ovipositor sheath about half as long as metatibia.

MALE. Unknown.

Etymology. Magnus (Latin), large and oculus (Latin), eye. Refers to the relatively large eyes.

Comments. Anastatus magnoculus is closely related to A. lichtensteini, females of both species being brachypterous and without a raised median lobe on the mesoscutum. They may be distinguished by the characters given in the key (couplet 10); also, in A. lichtensteini a posterior ocellus is separated from the adjacent orbit by about two ocellar diameters (one in magnoculus), the flagellum is relatively shorter with Fu7 slightly transverse (Fu7 slightly elongate in magnoculus), the intertorular prominence has a very fine median carina (rounded in magnoculus) and the metatarsus is as broad as the protarsus (thinner than protarsus in magnoculus).

Biology. Host unknown but A. magnoculus, like $A$. lichtensteini, is probably a parasitoid in oothecae of Mantidae.

A. oscari (Ruthe, 1859: 124)

Eupelmus oscari Ruthe, 1859

Recorded from Spain by Askew et al. (2001) on the basis of one female from Zaragoza, Pina de Ebro, 21.vii.1991, JBZ. 
Arachnophaga Ashmead, 1896

Mercetina Bolívar, 1933 (synonymy in Gibson, 1995)

The African and European species previously known under Mercetina are all assigned to Arachnophaga subgenus Parasolindenia Brues, 1907 by Gibson (1995). Females are brachypterous and are characterized by the toruli being placed entirely below the lower orbit, elongated tegulae which are much longer than the prepectus, relatively long ventral mesotarsal pegs and striate scutellum.

\section{Key to females of species of Arachnophaga Ashmead from Spain}

1. Scutellum with median longitudinal crest which bears a line of long, dark brown setae; metacoxa with outer face bare (ventrally pilose); ovipositor sheath about 0.5 times as long as metatibia ..................... matritensis (Bolívar)

- Scutellum medially rather flat without a longitudinal line of dark setae, but with scattered, short, white setae; metacoxa with outer face densely adorned with short, white hairs; ovipositor sheath 0.7-0.8 times as long as metatibia picardi (Bernard)

The male of $A$. picardi is redescribed below; that of $A$. matritensis is not certainly known but an unidentified male eupelmid, which might be $A$. matritensis, is also discussed below.

\section{A. matritensis (Bolívar, 1933: 208-209)}

Mercetina matritensis Bolívar, 1933

The unique specimen on which Bolívar based his description of Mercetina and M. matritensis was not found in MNCN. It was caught by Bolívar on 6.vi.1918 at Vaciamadrid (Madrid). A second Spanish example from Monegros (Zaragoza), captured in a yellow tray in 1990 (JBZ), was recorded by Askew et al. (2001), and three further female examples in ZMAN (Amsterdam) are from Cuenca, Motilla del Palancar, 24-29-v.1987, M. J. Gijswijt; Soria, El Burgo de Osma on Juniperus thurifera, 21-25.v.1990, M. J. Gijswijt, and the Canary Islands, Gran Canaria, Ayaguares $9 \mathrm{~km}$. NNW of Maspalomas, 6.iv.1987, A. C. \& W. N. Ellis, A. M. J. \& R. T. Simon Thomas.

A. picardi (Bernard, 1936: 71-72)

Anastatus picardi Bernard, 1936

Described originally in Anastatus and later redescribed and transferred to Mercetina by Ferrière (1954), this species was hitherto apparently known only from the south of France where it had been reared from oothecae of Mantidae (Ameles, Iris, Empusa) (Ferrière, 1954).

After his original description of $A$. picardi, Bernard (1936) noted having 13 우 우 $80^{7} 0^{\circ}$ "types' reared from oothecae of Ameles decolor collected at Fréjus and Nice. The Muséum National d'Histoire Naturelle (Paris) has just a single Bernard specimen; this has been examined. It is labelled as emerging on 3.x.1936 from an ootheca of Empusa collected at Banyuls [Pyrénées Orientales] and is not, therefore, from the type series (although having a red printed 'TYPE' label). There are 2 우 $ᄋ$ 10 labelled as 'cotypes' in the Natural History Museum (London) (G. Gibson pers. com.).

New records for Spain: 2 우 $10^{\pi}$, Sevilla, south-east, 1986, ex mantid ootheca, M. Boness; 6 우 우 $30^{7} 0^{7}$, Jaén, Coto nacional de Cazoria (1800 $\mathrm{m})$, ex Ameles ?spallanzania ootheca with Iridophagus (Torymidae) collected ix.1976 emerged viii.1977, M. J. Morgan.

MALE. Body entirely dark blue-green with violet tints on mesoscutum and scutellum; femora dark, metallic blue-green; tibiae dark and weakly metallic; protarsus light brown, mesotarsus with T4 and T5 brown, otherwise whitish, metatarsus with T3-T5 brown, T2 brown dorsally, T1 and ventral part of T2 whitish. Wings clear. Length $2.0 \mathrm{~mm}$.

Face with lower edge of torulus slightly above lower orbit, lower face with short, white hairs which are very slightly flattened; genal setae unmodified. Antenna with scape linear, about four times as long as broad; pedicel ventrally with one long seta; flagellum compact, filiform, Fu1 about 2.7 times as long as broad and 3.0 times as long as pedicel, funicle segments with very short pilosity and several irregular transverse rows of short sensillae. Mandible tridentate.

Propodeum without median carina, medially faintly reticulate, almost smooth. Metacoxa with a few hairs on dorsal surface, outer surface bare.

Forewing with basal cell pilose and speculum not developed, the pilosity distad of basal vein rather sparse but absent only immediately behind parastigma. Ratio of lengths of costal cell: marginal vein: stigmal vein; postmarginal vein as 15:8:4:6.

Gibson (1995) gave details of male Arachnophaga, emphasising their morphological diversity. The important features of male $A$. picardi would seem to be the rather high position of the antennal toruli, with the ventral margin above the lower orbit (usually below), only a single long ventral seta on the pedicel and bare outer face of the metacoxa.

\section{Arachnophaga? sp. indet.}

Known only from males collected in Malaise traps and assigned to Arachnophaga because of 
their similarity to male $A$. picardi. They are quite frequent in Spain, and are probably associated with brachypterous females because no matching females have been captured with the males in Malaise traps. They possibly represent the unknown male of A. matritensis.

Spain: Granada, Calahonda, $20^{\top} \sigma^{\pi}$ vii.1987, $10^{\top}$ vii.1988, L. Lockey; Madrid, El Ventorillo, $120^{7} \sigma^{7}$ vii.1991, A. Garrido; Zaragoza, Pina de Ebro, $10^{\pi}$ x.1990, $50^{x} \sigma^{x}$ v.1991, $230^{7} \sigma^{\prime \prime}$ vi.1991, $160^{7} \sigma^{\pi}$ vii.1991, 340 $0^{7}$ viii.1991, $210^{7} 0^{7}$ 1x.1991, all JBZ.

MALE. Body blue-green to green with violet tints most evident in larger specimens; femora and tibiae dark, metallic, with tibio-femoral joints narrowly yellowish, as also is apex of protibia; tarsi brown with T1-T3 of mesotarsus and T1 and T2 of metatarsus white ventrally. Wings clear with pilosity rather pale and faint. Length $0.8-2.0 \mathrm{~mm}$.

Lower face with short white hairs which are slightly flattened in larger specimens; no modified genal setae. Antennal torulus with lower edge somewhat below lower orbit; scape 3.2-3.4 times as long as broad; pedicel ventrally with two or three long setae; flagellum compact, filiform, slightly tapering; F1 about 2.7 times as long as broad and 2.7 times as long as pedicel; funicle segments with very short pilosity and several irregular transverse rows of short sensillae. Mandible tridentate.

Thorax ventrally with rather dense, white pilosity; propodeum with median carina sometimes finely and faintly indicated, medially faintly reticulate, almost smooth. Metacoxa with hairs on dorsal surface to base, outer surface bare.

Forewing basal cell pilose; speculum absent although hairs behind parastigma are white and inconspicuous giving the illusion of a speculum. Ratio of lengths of costal cell: marginal vein: stigmal vein: postmarginal vein as 32:16:8:11; stigma rather large, fully twice as long as broad and separated from postmarginal vein by twice its height.

COMMENTS. Similar to the male of A. picardi but differing in having the toruli lower, their ventral edges below the level of the lower margins of the eyes, the scape broader, wings with paler venation and indistinct pilosity. The stigma is separated from the postmarginal vein by 2.0 times its height whereas in A. picardi it is separated by 2.5 times its height.
Brasema Cameron, 1884

Cerambycobius Ashmead, 1896 (synonymy in Gibson, 1995)

Represented in Spain by a single known species.

B. ephedricola Askew, 1998: 814-815

An ectoparasitoid in galls of Eurytoma gallephedrae Askew (Eurytomidae) on Ephedra nebrodensis. The species was discovered in Zaragoza, Sierra de Alcubierre near Retuerta de Pina, and is described, with an account of its biology, in Askew \& Blasco-Zumeta (1998).

\section{Calymmochilus Masi, 1919}

Three of four European species of Calymmochilus, one of which is described as new below, occur in Spain.

\section{Key to Spanish species of Calymmochilus}

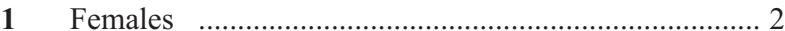

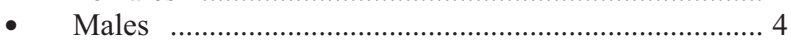

2(1) Brachypterous, forewing just reaching to base of gaster, truncate with apical margin slightly concave; mandible over three times as long as broad, arcuate with a small subapical tooth; head in dorsal view with frons relatively shallowly excavated; scape mainly pale; larger, length 3.0$4.6 \mathrm{~mm}$................................. dispar Boucek \& Andriescu

- $\quad$ Macropterous; mandible at most about 2.1 times as long as broad with subapical tooth not or hardly developed; head in dorsal view with frons more deeply excavated; scape sometimes infuscate; smaller, length up to about $2.3 \mathrm{~mm}$........ 3

3(2) Legs with meso- and metacoxae dark, femora and tibiae mostly brownish; scape and gaster dark; forewing with brown discal cloud; gaster in dorsal view 2.7 times as long as broad, distinctly longer than rest of body; body length $2.0 \mathrm{~mm}$ or more .................. subnubilus (Walker)

- Legs (including coxae) yellow; scape and posterior half of gastral dorsum yellow, anterior half of gaster yellowish brown, a brown stripe runs from cercus to just before apex; forewing discally faintly yellow; gaster in dorsal view 1.8 times as long as broad, about as long as rest of body; body length 1.6-1.8 mm ............. delphinus $\mathrm{sp}$. $\mathrm{n}$.

4(1) Forewing stigma relatively narrow, separated from postmarginal vein by more than twice its height and with uncus at least as long as height; head and mesosoma dorsally dark brown with violet tints; gaster less strongly compressed; head in dorsal view with eyes separated by about 2.5 times breadth of an eye; antenna with Fu1 slightly less than 3.0 times as long as broad ............ subnubilus and delphinus Forewing stigma larger, rounded, separated from postmarginal vein by less than twice its height and with uncus shorter than height; head and mesosoma dorsally black with faint greenish to bronze (not violet) tints; gaster strongly compressed (in air-dried specimens); head in dorsal view with eyes separated by about 3.5 times breadth of an eye; antenna with funicle segments longer, Fu1 more than 3.0 times as long as broad .. dispar 


\section{Calymmochilus delphinus Askew sp. n. (fig. 6)}

Material: All specimens Spain, Granada, Calahonda, Malaise trap, vii.1987, vii.1988 or vii.1989, L. Lockey.

Holotype ㅇ․ . Collected 1989. Deposited in MNCN.

Allotype $\sigma^{\prime}$. Collected 1988. Deposited in MNCN. 1989.

Paratypes. 1 우 $40^{7} \sigma^{7}$ collected in 1988, 2 우 우 collected in

AdDitional MATERial. $3 \sigma^{\pi} \sigma^{\pi}$ 1987, $1 \sigma^{\pi}$ 1988, $3 \sigma^{\pi} \sigma^{\pi} 1989$.

FEMALE. Head and mesosoma black with violet tints (strongest on face), supraclypeal area slightly green; antenna brown with scape yellow. Forewing weakly yellowish with a brown mark proximally in basal and costal cells; venation yellow except for brown proximal half of submarginal vein. Legs uniformly yellow, only tarsal claws brown. Gaster dorsally brownish in basal half, apical half yellow with a brown stripe running from cercus almost to apex of gaster, ventral surface mostly yellow. Length $1.6-1.8 \mathrm{~mm}$.

Head in dorsal view almost twice as broad as long (55:29), frons deeply excavated, temple about 0.1 times length of eye; POL:OOL as 5:4. Head in front view (fig. 6) slightly broader than high (13:12); scrobal area strongly excavated but not clearly defined laterally; face receding below toruli, torulus far below eye and only about one diameter above level of base of mandible; clypeus semicircularly protruding with a reflexed rim which is crossed by a number of fine ridges, each ridge ending on the margin of the clypeus as a minute tooth - teeth much smaller (fig. 6) than in C. dispar (fig. 7) - Mandible about twice as long as basal breadth with a single slightly curved, pale tooth. Antenna (fig. 6) with pedicel plus flagellum 1.4 times breadth of head; scape 1.2 times as long as an eye; pedicel almost 3.0 times as long as broad; anellus slightly longer than broad; Fu1 plus anellus shorter and narrower than pedicel; Ful about twice as long as broad, the following segments subequal in length but progressively broadening, Fu7 about 1.4 times as long as broad and broader than pedicel; clava almost as long as combined Fu4-Fu7, 3.1 times as long as broad, apically pointed with a pad of micropilosity on inner faces of $\mathrm{C} 2$ and $\mathrm{C} 3$.

Mesosoma in dried material usually flexed at scuto-scutellar suture; scutellum and axillae in same plane and strongly reticulate, dull; mesopleuron with raised and moderately coarse reticulate sculpture. Mesotarsus with a double row of brownish yellow pegs on ventral surfaces of 3 or 4 proximal segments; mesotibial spur relatively short, not twice as long as apical breadth of tibia.
Forewing not quite reaching apex of gaster, evenly pilose without a speculum, the hairs short and dense; relative lengths of costal cell: marginal vein: stigmal vein: postmarginal vein as $36: 24: 8: 15$; submarginal vein with proximal half thicker than distal half, the wing slightly flexed at junction of the two thicknesses.

Gaster ovate, about 1.8 times as long as broad, its apex bluntly rounded; T7 completely concealing ovipositor in dorsal view.

MALE. Darker than female; scape, legs and gaster mostly brown to black; wings clear. Length 0.8 $1.2 \mathrm{~mm}$.

Etymology. Delphinus (Latin), a dolphin, to which the female gaster bears a fanciful resemblance.

Comments. Females of $C$. delphinus and C. subnubilus are readily distinguished on colour characters, as indicated in the key, although morphologically they are close. No reliable character has been found to separate males of these two species, although characters given in the key (above) to distinguish them from male $C$. dispar tend to be present in a more extreme form in $C$. delphinus than in C. subnubilus.

\section{C. dispar Boucek \& Andriescu, 1967: 234-238}

Boucek (1977) recorded C. dispar from Spain and two males from Jaén, 1974, RRA, were identified as $C$. dispar by Boucek in 1976. Further records are Alicante, Moraira, 1 \& 1989, R. Wahis (ZMAN); Barcelona, $10^{7}$ undated, RGM (MNCN); Málaga, Alfarnatejo, $10^{7}$ 1998, RRA and Ronda, $10^{7} 1994$, M. J. Gijswijt (ZMAN); Madrid, Manzanares el Real, $10^{\top} 1995$, F. M. Fontal (MNCN).

C. subnubilus (Walker, 1872: 81)

Eupelmus subnubilus Walker, 1872

Calymmochilus atratus Masi, 1919 (synonymized in Boucek, 1970)

Newly recorded for Spain (Zaragoza) in Askew et al. (2001). Additional records: Burgos, Sierra de la Demanda, Pineda de la Sierra, 1 우 30.ix.1994, RRA; Jaén, 1 ㅇ x.1916, RGM (MNCN) (det. subnubilus by Boucek in 1984); Madrid, El Pardo (El Goloso), Malaise trap, 1 ㅇ v.1991, $10^{7}$ ix.1991, JNA (MNCN); E1 Ventorillo, Malaise trap, 1 ㅇ x.1989, 1 ㅇ vi.1990 (det. G. Gibson, 1991), JNA; $20^{7} \sigma^{7}$ 13.vii.1991, A. Garrido (all MNCN).

New record for the Canary Islands: La Palma, Parque Nacional de la Caldera de Taburiente, on 
Chaemocytisus, 1 우 25.ix.1999, M. Sanchez Ruiz. From the same locality $70^{7} 0^{7}$ Calymmochilus, which are probably conspecific with the above female, were captured in a Malaise trap, viii and ix.1999, T. Domingo Quero.

\section{Eupelmus Dalman, 1820}

Since our paper on Eupelmus (Askew \& NievesAldrey, 2000), we have gathered further information on some Spanish species and located type material of Bolívar's species Eupelmus capillaris (see under E. fuscipennis), E. splendens (under E. matranus) and E. valentinus Bolívar (under E. testaceiventris).

\section{E. annulatus Nees, 1834}

New provincial record: Ávila, Peguerinos, 1994, JNA (MNCN).

\section{E. atropurpureus Dalman, 1820}

New provincial record: La Coruña, Puerto del Son, 1994, JNA (MNCN).

\section{E. fuscipennis Förster, 1860}

Eupelmus capillaris Bolívar, 1933 was synonymized under E. fuscipennis by Askew \& NievesAldrey (2000), although type material of capillaris had not been examined. Subsequently two conspecific females, both collected from Madrid, El Pardo by RGM, were located in MNCN. One of these specimens is labelled holotype Eupelmus capillaris, the other paratype E. capillaris, by Boucek 1976. Compared to French material of E. fuscipennis, these specimens are rather small and have clear wings, but they are considered to lie within the range of variation of $E$. fuscipennis.

\section{E. hungaricus Erdös, 1959}

The species treated under Eupelmus hungaricus by Askew \& Nieves-Aldrey (2000) is newly transferred to the genus Reikosiella (see below).

\section{E. juniperinus Bolívar, 1933}

The type series of E. juniperinus consists of four females from Madrid, Zarzalejo on Juniperus oxycedrus, with one of the paratypes collected 27.vi.1924 by RGM. All four specimens were stated to be in MNCN (Bolívar, 1933). The location of two paratypes in MNCN was reported by Askew \& Nieves-Aldrey (2000) and a third paratype labelled
'El Escorial, G. Mercet, Zarzalejo 21.6.24' has now been found in the same collection. The holotype remains missing.

\section{E. matranus Erdös, 1947}

Eupelmus splendens Bolívar, 1933 (homonym of E. splendens Giraud, 1871)

The holotype female of $E$. splendens Bolívar has now been located in MNCN. It is labelled 'Loeches, Mercet' and 'Eupelmus splendens Bolívar Holotype det. Z. Boucek 1976'.

\section{E. microzonus Förster, 1860}

Newly recorded from the Canary Islands ( $\mathrm{La}$ Gomera) by Koponen \& Askew (2002).

\section{E. rostratus Ruschka, 1921}

Two females collected Madrid, El Pardo (El Goloso), Malaise trap, ix.1991, Nieves \& Rey, may be E. rostratus but have extensively testaceous bodies and the forewings are marked with two separate transverse infuscate bands, one behind the parastigma and basal half of the marginal vein, the other behind the postmarginal and apical quarter of the marginal veins. More material is required to firmly establish their identity.

\section{E. testaceiventris (Motschulsky, 1863)}

Eupelmus valentinus Bolívar, 1933 (synonymy in Askew \& Nieves-Aldrey, 2000)

A female labelled 'Betera, Valencia, Moroder' and 'Holotype E. valentinus det. Z. Boucek 1993' is in MNCN.

\section{E. (Macroneura) aseculatus Kalina, 1981}

A female reared from a gall of Andricus quercusradicis (Fabricius) sex. gen. (Hym., Cynipidae), Madrid, Casa de Campo, 1983, JNA (MNCN) represents a new host record for Spain.

E. (M.) maculatus (Ferrière, 1954)

Second record for Spain: 1 ㅇ, Barcelona, Calella de Costa, 1971, collected and determined Z. Boucek (MNCN).

\section{E. (M.) seculatus (Ferrière, 1954)}

New host records: 1 \& ex gall Plagiotrochus australis (Mayr) sex. gen. (Hym., Cynipidae) on Quercus ilex, Madrid, Robledo de Chavela, 1986, JNA (MNCN); $1 \%$ ex gall $P$. quercusilicis (Fabricius) sex. gen., Salamanca, La Flecha, 1982, JNA (MNCN). 


\section{Merostenus Walker, 1837}

M. excavatus (Dalman, 1820: 382)

Eupelmus excavatus Dalman, 1820

New record for Spain: 10', Guipúzcoa, San Sebastian, Orio, 12.ix.1964, RRA.

Gibson (1995) described the male of M. excavatus. The species is known as a parasitoid of Phytonomus variabilis Herbst (Col., Curculionidae) but is certainly polyphagous (Boucek, 1977).

\section{Reikosiella Yoshimoto, 1969}

\section{R. hungarica (Erdös, 1959: 327-330) new combination}

The identification and resulting new combination was based on examination of the holotype female of Eupelmus hungaricus Erdös in the Hungarian Natural History Museum, Budapest, by G. Gibson (pers. com.).

This is a distinctive eupelmid with white second to fifth funicle segments. A single female from Zaragoza was reported by us in 2000 (under the name Eupelmus hungaricus), and another Spanish female from Madrid, El Ventorillo, Malaise trap, 916.vi.1989, JNA (MNCN) has since been found. This latter specimen is labelled 'Reikosiella (Hirticauda) hungarica det. G. Gibson'. Hirticauda Boucek, 1988 is considered a subgenus of Reikosiella Yoshimoto, 1969 by Gibson (1995), but no reference is made to E. hungaricus in the latter work.

A third female specimen, Jaén, Carolina, 20.iv.2002, M. J. Gijswijt (ZMAN) has been seen.

\section{ACKNOWLEDGEMENTS}

We are very grateful to the following who have supplied us with specimens and information: the late H. G. Allcard, Marcos Báez, Javier Blasco-Zumeta, Martin Boness, Zdenek Boucek, Theo Gijswijt, Leslie Lockey and Juli Pujade-Villar. The paper has been much improved as a result of very helpful criticism by Gary Gibson. Mme C. Villemant kindly lent us Bernard's material housed in the Muséum National d'Histoire Naturelle, Paris. The project has been greatly helped by grants to RRA from the European Commission Human Potential Programme through BIODIBERIA in 2002 and 2003, and to JNA from the Spanish Ministry of Science and Technology, research project REN 200203518, and the project "Inventory and study of the invertebrate faune of the Caldera de Taburiente National Park", Organismo Autónomo, Parques Nacionales.

\section{References}

ASHMEAD, W. H., 1896. On the genera of the Eupelminae. Proceedings of the Entomological Society of Washington, 4: 4-20.
AshmeAD, W. H., 1904. Descriptions of new Hymenoptera from Japan. II. Journal of the New York Entomological Society, 12: 146-165.

Askew, R. R. \& Blasco-Zumeta, J., 1998. Insects associated with galls of a new species of Eurytomidae (Hymenoptera: Chalcidoidea) on Ephedra nebrodensis in Spain. Journal of Natural History, 32: 805-821.

Askew, R. R., Blasco-Zumeta, J. \& Pujade-Villar, J., 2001. Chalcidoidea y Mymarommatoidea (Hymenoptera) de un sabinar de Juniperus thurifera L. en Los Monegros, Zaragoza. Monografias de la Sociedad Entomológica Aragonesa, 4: 1-76.

Askew, R. R. \& Nieves-Aldrey, J. L., 2000. The genus Eupelmus Dalman, 1820 (Hymenoptera, Chalcidoidea, Eupelmidae) in peninsular Spain and the Canary Islands, with taxonomic notes and descriptions of new species. Graellsia, 56: 49-61.

BÁEZ, M. \& AsKew, R. R., 1999. New records of Chalcidoidea (Hymenoptera) from the Canary Islands. Boletín de la Asociación Española de Entomología, 23: 65-82.

BERNARD, F., 1935. Un nouvel Hyménoptère parasite des oothèques de Mantides: Anastatus ameleophagus n. sp. Bulletin de la Société Zoologique de France, 60: 208-212.

BERnARD, F., 1936. Morphologie et comportement des Anastatus parasites d'oothèques de Mantides. Bulletin de la Société Entomologique de France, 41: 69-75.

Bolívar y Pieltain, C., 1923. Estudios sobre Calcídidos de la Familia Eupélmidos. Revista de Fitopatología, 1: 114-122.

Bolívar y Pieltain, C., 1933. Estudio de algunos Eupélmidos nuevos de España (Hym. Chalc.). Eos, 9: 195-209.

Bolívar y Pieltain, C., 1934. Estudio monográfico de las especies españolas del género Anastatus Motsch. (Hym. Chalc). Eos, 10: 273-292.

BouCEK, Z., 1970. Contribution to the knowledge of Italian Chalcidoidea, based mainly on a study at the Institute of Entomology in Turin, with descriptions of some new European species. Estratto dalle Memorie della Società Entomologica Italiana, 49: 35-102.

BouceK, Z., 1977. A faunistic review of the Yugoslavian Chalcidoidea (Parasitic Hymenoptera). Acta entomologica Jugoslavica, 13 suppl.: 1-145.

BoucEK, Z., 1988. Australasian Chalcidoidea (Hymenoptera). A Biosystematic Revision of Genera of Fourteen Families, with a Reclassification of Species. C.A.B. International. Wallingford. 832 pp.

BouceK, Z. \& ANDRIESCU, I., 1967. Notizen über die Gattung Calymmochilus Masi, mit Beschreibung einer neuen Art aus Südeuropa (Hymenoptera, Eupelmidae). Acta Entomologica Musei Nationalis Pragae, 37: 233-238. 
Brues, C. T., 1907. New chalcid-flies from Cape Colony Bulletin of the Wisconsin Natural History Society, 5: 46-53.

Cameron, P., 1884. Hymenoptera (Families Tenthredinidae-Chrysididae). Biologia Centrali-Americana. Insecta, 1: 1-487.

Ceballos, G., 1956. Catálogo general de los Himenópteros de España. Instituto Español de Entomología. Madrid. 420 pp.

DAlman, J. W., 1820. Försök till Uppställning af Insekfamiljen Pteromalini, i synnerhet med åfseende på de i Sverige funne arter. Kungliga Svenska Vetenskapsakademiens Handlingar, 41: 340-385 (partim).

ERDös, J., 1947. Eupelmus matranus spec. nov. (Hymen., Chalc., Eupelmidae). Folia entomologica Hungarica, 2(s.n.): 68-70.

ERDÖs, J., 1959. Species nova Eupelmidarum in territorio reservato Bátorliget detecta. Folia entomologica Hungarica, 12: 327-330.

FERriÈre, C., 1954. Eupelmides brachyptères (Hym. Chalcidoidea). Mitteilungen der Schweizerischen Entomologischen Gesellschaft, 27: 1-21.

FöRSTER, A., 1860. Eine Centurie neuer Hymenopteren. Verhandlungen der naturhistorischen Vereins der Preussischen Rheinlande, 17: 93-153.

FourCROY, A. F. DE, 1785. Entomologica Parisiensis. Pars secunda. Paris. 311 pp.

GiBson, G. A. P., 1995. Parasitic wasps of the subfamily Eupelminae: classification and revision of world genera (Hymenoptera: Chalcidoidea: Eupelmidae). Memoirs on Entomology International, 5: 1-421.

Kalina, V., 1981. The Palearctic species of the genus Anastatus Motschulsky, 1860 (Hymenoptera, Chalcidoidea, Eupelmidae), with descriptions of new species. Silvaecultura Tropica et Subtropica, 1: 3-25.

Koponen, M. \& Askew, R. R., 2002. Chalcids from Madeira, Canary Islands and Azores (Hymenoptera, Chalcidoidea). Vieraea, 30: 115-145.

MASI, L., 1919. Materiali per una fauna dell' Arcipelago Toscano. XI. Calcididi del Giglio. Seconda serie: Eurytominae (seguito), Eucharidinae, Encyrtinae, Eupelminae (partim). Annali del Museo civico di Storia naturale Giacoma Doria, Genova, 48: 277-337.
MotschulsKy, V. DE, 1859. Insectes des Indes Orientales, et de contrées analogues. Études Entomologiques, 8: 25-118.

Nees ab Esenbeck, C. G., 1834. Hymenopterorum Ichneumonibus affinium monographiae, genera Europaea et species illustrantes, 2. Stuttgart \& Tubingen. $448 \mathrm{pp}$.

RuschKA, F., 1921. Chalcididenstudien. I. Teil. Verhandlungen der Zoologisch-Botanischen Gesellschaft in Wien, 70: 234-315.

Ruthe, J. F., 1859. A. Försters Systematik der Proctotrupiden und Al. H. Halidays Systematik der Diapriiden. Berliner Entomologische Zeitschrift, 3: 1-118.

TACHIKAWA, T., 1965. Iconographia Insectorum Japonicorum colore naturali, 3: 281 .

WAlker, F., 1837. Monographia Chalciditum. Entomological Magazine, 4: 349-364.

Walker, F., 1872. Notes on Chalcidiae. Part $V$. Encyrtidae, Myinidae, Eupelmidae, Cleonymidae, Spalangidae, Pirenidae. E. Newman. London. 18 pp. (71-88).

Yosнiмото, C. M., 1969. Description of a new genus of Eupelminae from Hawaii with remarks on its biology (Hymenoptera: Encyrtidae). Pacific Insects, 11: 627-632. 